\title{
Innovative High-Surface-Area CuO Pretreated Cotton Effective in Bacterial Inactivation under Visible Light
}

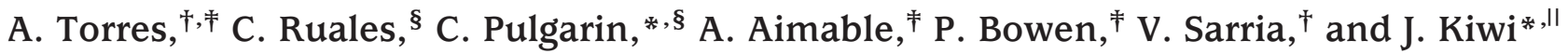 \\ Department of Chemistry, Universidad de los Andes, Cra1E No 18A-10, Bogota, Colombia, EPFL-STI-IMX-LTP, \\ Powder Technology Laboratory, Materials Institute, MXD 334, Station 12, Swiss Federal Institute of \\ Technology, CH-1015 Lausanne, Switzerland, EPFL-SB-ISIC-GGEC, Station 6, Swiss Federal Institute of \\ Technology, CH-1015 Lausanne, Switzerland, and EPFL-SB-ISIC-LPI, Station 6, Swiss Federal Institute \\ of Technology, $\mathrm{CH}-1015$ Lausanne, Switzerland
}

\begin{abstract}
This study presents the first report on enhanced bacterial inactivation of $E$. coli by RF-plasma pretreated cotton with high-surface-area CuO powders compared with nonpretreated cotton textiles. The high-surface-area CuO (65 m/g) powder was fully characterized. The E. coli inactivation proceeded in the dark and was accelerated under visible and sunlight irradiation even at very low levels of visible light irradiation. The effect the RF-plasma pretreatment of the cotton on the binding of CuO, applied light dose, the amount of $\mathrm{CuO}$ loading and initial $E$. coli concentration on the inactivation kinetics of $E$. coli is reported in detail.
\end{abstract}

KEYWORDS: RF-plasma $\bullet$ CuO high SSA $\bullet$ cotton $\bullet$ E. coli; visible light

\section{INTRODUCTION}

$\mathrm{T}$ he manufacturing of high value added products such as bactericide textiles has increased rapidly in the past few years $(1-5)$. This development also opened new interest in the pretreatment or activation of the surface of textiles by RF-plasma, vacuum-UVC light irradiation $(6,7)$, and corona discharge $(8,9)$ to deposit nanosized bactericide semiconductors and metals/metal-oxides. Bactericide textiles have been developed and intensively investigated recently by Daoud et al. $(10,11)$ and many other laboratories. Many bactericide agents have been applied on textiles like trichlosan, chitosan, N-halamine, polyhexamethylene, and peroxoacids (12), but poor efficiency and high toxicity besides leaching problems have made many of them unsuitable for long-term use (13). But silver has shown effective bacterial inactivation properties with low toxic impact to mammalian cells $(13,14)$. The bactericide properties of silver have been known for a long time. The effective of bactericide textiles remains for a long time with a sustained efficiency and the silver can be fixed on the textile without stabilizers $(15,16)$. Our group has recently reported the loading of Ag on different textiles like cotton, wool and polyester previously activated by RF-plasma and vacuumUVC $(17,18)$. These studies indicated that the pretreatment of textile fibers by low pressure RF-plasma and Vacuum-UVC

* Corresponding author.

Received for review April 27, 2010 and accepted July 7, 2010

† Universidad de los Andes.

* EPFL-STI-IMX-LTP.

$\S$ EPFL-SB-ISIC-GGEC.

"EPFL-SB-ISIC-LPI

DOI: 10.1021/am100370y

2010 American Chemical Society increased the number of binding sites like: carboxylic acid $-\mathrm{COOH}$, peroxides $-\mathrm{O}-\mathrm{O}-$, percarboxylic acids, epoxides, lactams and other giving raise to organic functional groups to bind $\mathrm{Ag}$ (6) or $\mathrm{TiO}_{2}$ (7). These pretreatments roughens the textile surface also leading to (a) $\mathrm{C}-\mathrm{C}$ bond scission, (b) decrease in the $\mathrm{C}-\mathrm{H}$ bonds due to the destruction of intermolecular $\mathrm{H}$-bonding, and (c) introduction of additional $-\mathrm{C}=\mathrm{O}$ groups (as observed by XPS) having the effect of increasing the textile polarity and hydrophilicity which facilitates the adhesion between nanoparticles and the fabric (18).

The bactericide properties of $\mathrm{Cu}$ have been widely reported $(19,20)$. Recently, Borko and Gabbay (21) have reported bactericide, antiviral, algicide, and fungicide textiles that sustain well washing cycles loaded with $\mathrm{CuO} 1 \%$. This textile is effective against E. coli, Staphylococcus aureus, and the fungi Candida albicans. These textiles are used in hospitals and laboratories using $\mathrm{CuO}$ against already-resistant antibiotics involving nosocomial infections and should not allow the development of resistant microbes, should be safe to humans, and do not cause skin irritation when applied externally $(22,23)$. Besides the known oxidation of organic pollutants in the dark or light $(24,25)$, recently our laboratory has reported the synthesis of large surface area CuO effective in the E. coli inactivation in the dark and under visible light $(26,27)$. The use of $\mathrm{CuO}$ textiles in external applications for skin treatments requires a stable, effective and long-lasting nanoparticle deposit of $\mathrm{CuO}$ for safe external applications. This point has been addressed describing $\mathrm{CuO}$ impregnated textiles with effective biocidal properties (28).

The present study addresses (a) the high-surface-area preparation and characterization of $\mathrm{CuO}$, (b) the adhesion of the nanoparticulate $\mathrm{CuO}$ on the cotton activated by RF- 


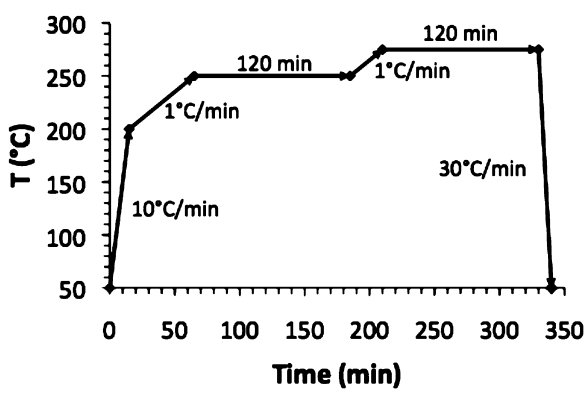

FIGURE 1 . Thermal cycle for the Cu-oxalate decomposition under air $(20 \mathrm{~mL} / \mathrm{min}, 1$ atm. P).

plasma in comparison with non plasma activated surfaces $(6,7)$, and (c) the evaluation of E. coli inactivation by cotton/ $\mathrm{CuO}$ in the dark and under light.

\section{EXPERIMENTAL SECTION}

Reagents and Synthesis of High-Surface-Area CuO. Chemicals $\mathrm{Cu}\left(\mathrm{NO}_{3}\right)_{2} \cdot 3 \mathrm{H}_{2} \mathrm{O}, \mathrm{Na}_{2} \mathrm{C}_{2} \mathrm{O}_{4}$, Merck reagents and hydroxypropyl-methylcellulose (HPMC 100, $M_{\mathrm{w}} 64000 \mathrm{~g} / \mathrm{mol}$, Hercules $\mathrm{GmbH}$ ) were pro-analysis (p.a.) and used as received. $\mathrm{Cu}\left(\mathrm{NO}_{3}\right)_{2}$ and $\mathrm{Na}_{2} \mathrm{C}_{2} \mathrm{O}_{4}$ solutions were prepared in ultrapure water previously boiled to eliminate dissolved $\mathrm{CO}_{2}$. These solutions were then filtered at $0.2 \mu \mathrm{m}$ to eliminate dust. The stock solutions were stored in closed vessels to avoid further contamination.

For the preparation of the large-surface-area $\mathrm{CuO}$ powders, $\mathrm{Cu}\left(\mathrm{NO}_{3}\right)_{2}$ and $\mathrm{Na}_{2} \mathrm{C}_{2} \mathrm{O}_{4}(0.02 \mathrm{M})$ solution were prepared just before use to avoid $\mathrm{CO}_{2}$ contamination and mixed in a $5 \mathrm{~L}$ batch under vigorous stirring (1500 rpm) for $30 \mathrm{~min}$ and subsequently aged for $2 \mathrm{~h}$ as shown in reaction 1

$$
\mathrm{Cu}^{2+}+2 \mathrm{NO}_{3}^{-}+2 \mathrm{Na}^{+}+\mathrm{C}_{2} \mathrm{O}_{4}^{2-} \leftrightarrow \mathrm{CuC}_{2} \mathrm{O}_{4}+2 \mathrm{NaNO}_{3}
$$

The $\mathrm{Cu}$-oxalate was then collected by filtration using $0.2 \mu \mathrm{m}$ filters and dried $24 \mathrm{~h}$ at $70^{\circ} \mathrm{C}$. The thermal decomposition of Cu-oxalate into copper oxide was carried out in a tubular furnace (Linderberg) under airflow $(20 \mathrm{~mL} / \mathrm{min})$. The temperature profile of the process is shown in Figure 1. This treatment avoids overheating due to the furnace inertia and provides an accurate control of the temperature as required in the synthesis of highsurface-area $\mathrm{CuO}(29)$.

The $\mathrm{CuO}\left(65 \mathrm{~m}^{2} / \mathrm{g}\right)$ was deposited on bleached cotton received from Cilander AG, Cilanderstr. 17, CH-9101, Herisau. The cotton samples $(2 \times 2 \mathrm{~cm})$ were fist activated by RF- plasma source from Harrick Corp, UK with a generator source of 13.56 $\mathrm{MHz}, 100 \mathrm{~W}$ at a pressure of 1 Torr for $30 \mathrm{~min}$. This pretreatment introduced additional carboxylates, percarboxylates, epoxides, lactams, polyphenols, and peroxide groups on the cotton surface giving raise additional binding sites for $\mathrm{CuO}(6,7)$.

Then, the samples were immersed in a sonicated solution of $\mathrm{CuO}(0.2 \mathrm{~g} / \mathrm{mL})$ and heated for $1 \mathrm{~h}$ at $75^{\circ} \mathrm{C}$. The loading of the samples was completed in three steps: (a) first heating at 60 ${ }^{\circ} \mathrm{C}$ for $1 \mathrm{~h}$, (b) followed by heating at $100{ }^{\circ} \mathrm{C}$ for $15 \mathrm{~min}$, and finally (c) the loose $\mathrm{CuO}$ was sonicated out of the samples in distilled water for $5 \mathrm{~min}$ followed by drying at $60^{\circ} \mathrm{C}$.

Thermogravimetric Analysis of $\mathrm{CuO}$. The thermogravimetric analysis (TGA) of the oxalate decomposition was followed up to $600{ }^{\circ} \mathrm{C}$ airflow with a heating rate of $10^{\circ} \mathrm{C} / \mathrm{min}$ in the TGA, Mettler TGA/DSC/TMA analyzer.

X-ray Diffraction of CuO (XRD). The phase identification was carried out by means of an X-ray powder diffraction X'Pert diffractometer, Philips $\mathrm{Cu}-\mathrm{K} \alpha$ radiation. To determine the size of the primary crystallite, we applied the Scherer equation (see eq 2). The instrumental broadening was determined using alumina for large crystal sizes $>1 \mu \mathrm{m}$.

$$
d_{\mathrm{XRD}}=\left(K \lambda_{\mathrm{X}}\right) /\left(\beta_{\mathrm{Xp}} \cos (\theta)\right)
$$

Where $K$ is equal to $0.9, \lambda_{\mathrm{x}}$ is the $\mathrm{X}$-ray (wavelength 1.54 Angstrom), $\beta_{\mathrm{xp}}$ is the integral breadth of the material (30), calculated using $\beta_{\text {Xp }}=\sqrt{ }\left(\beta^{2}-\beta^{2}\right.$ alumina).

Specific Surface Area (SSA) and Particle Size Distribution. The Brunauer-Emmett-Teller (BET) specific surface areas $S_{\text {BET }}\left(\mathrm{m}^{2} /\right.$ g) were determined from $\mathrm{N}_{2}$ adsorption isotherms (Micromeritics Gemini 2375) for the oxalate and CuO powders. The size of the primary particles, $d_{\mathrm{BET}}(\mathrm{nm})$ was calculated by assuming spherical monodisperse particles in eq 3, where $\rho$ was the density of the oxalate $\rho_{\text {oxalate }}=3.5 \mathrm{~g} / \mathrm{cm}^{3}$ and the density of the oxide $\rho_{\text {oxide }}=6.5 \mathrm{~g} / \mathrm{cm}^{3}$

$$
d_{\mathrm{BET}}=6 /\left(S_{\mathrm{BET}} \rho\right)
$$

The oxalate was dried before the SSA experimental determinations at $110^{\circ} \mathrm{C}$ in $\mathrm{N}_{2}$ for $1 \mathrm{~h}$, and the $\mathrm{CuO}$ was dried at $200{ }^{\circ} \mathrm{C}$. The particle size distribution (PSD) was collected using a laser diffraction method (Malvern Mastersizer S, $\rho=6.5 \mathrm{~g} / \mathrm{cm}^{3}$ and $n=2.6)$ by dispersing the $\mathrm{CuO}$ powder in a solution of poly(acrylic acid) $0.1 \mathrm{wt} \%, R=1.5(\mathrm{pH} \sim 10)$.

Electron Microscopy (SEM) and X-ray Fluorescence Determination of $\mathrm{Cu}$ on Textiles. The powder morphology was analyzed by scanning electron microscopy (SEM, Philips XL 30 FEG microscope). The SEM sample was prepared by dispersing the powder in ethanol. One drop of the suspension was then deposited on an Al-support and dried in air. The spectrometer used was an RFX, PANalytical PW2400. By this technique each element emits an X-ray of a certain wavelength associated with its particular atomic number.

Irradiation of Cotton/CuO Samples during E. coli Inactivation. Figure 6 shows in the insert the visible emission spectrum of the Osram Lumilux T8-L18W lamp (Winterthur, Switzerland) used to activate the cotton/CuO, having each lamp an output of $1.2 \mathrm{~mW} / \mathrm{cm}^{2}$. Figure 10 shows the results for $E$. coli bacterial inactivation mediated by a Suntest solar simulator CPS (Atlas $\mathrm{GmbH})$ equipped with a Xe-lamp $(830 \mathrm{~W})$. This source has a spectral distribution with $0.5 \%$ of the photons at wavelengths $<300 \mathrm{~nm}$, and $7 \%$ between 300 and $400 \mathrm{~nm}$ and this is shown in the insert to Figure 10. The light intensity was set at $27 \mathrm{~mW} / \mathrm{cm}^{2}$

Bacterial Inactivation under Light and in the Dark. The bacterial strain Escherichia coli K12 was inoculated in $5 \mathrm{~mL}$ of Luria-Bertani solution and grown during $8 \mathrm{~h}$ at $37{ }^{\circ} \mathrm{C}$ with constant agitation under aerobic conditions. Aliquots of the overnight culture were inoculated into a fresh medium and incubated aerobically at $37^{\circ} \mathrm{C}$ for $15 \mathrm{~h}$. At the stationary growth phase, bacteria cells were collected by centrifugation at $500 \mathrm{~g}$ for $15 \mathrm{~min}$ at $4^{\circ} \mathrm{C}$ and the bacterial pellets were washed three times and resuspended in a $\mathrm{NaCl} / \mathrm{KCl}$ solution.

The bactericide activity of cotton/CuO was tested on E. coli sterilizing $2 \mathrm{~cm}^{2}$ of cotton/CuO and cotton samples by autoclaving at $121^{\circ} \mathrm{C}$ for $2 \mathrm{~h}$. Then, $20 \mu \mathrm{L}$ aliquots of the culture in $\mathrm{NaCl} / \mathrm{KCl}$ solution were added to the cotton/CuO and cotton samples to adsorb the bacteria before irradiation. Next, the samples were transferred into a sterile $2 \mathrm{~mL}$ Eppendorf tube containing $1 \mathrm{~mL}$ of autoclaved $\mathrm{NaCl} / \mathrm{KCl}$ saline solution and mixed thoroughly using a vortex for $3 \mathrm{~min}$. Serial dilutions were made in $\mathrm{NaCl} / \mathrm{KCl}$ solution. One-hundred microliters of each aliquot was spread on the nutrient agar plate. Agar plates were incubated at $37{ }^{\circ} \mathrm{C}$ for $24 \mathrm{~h}$ before counting the CFU. Experiments were replicated at least two times and in some cases 


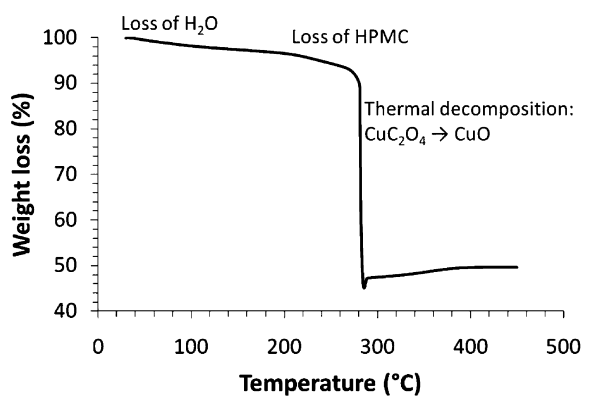

FIGURE 2. TGA curve of $\mathrm{Cu}$-oxalate powder (heating rate $10^{\circ} \mathrm{C} / \mathrm{min}$, air).

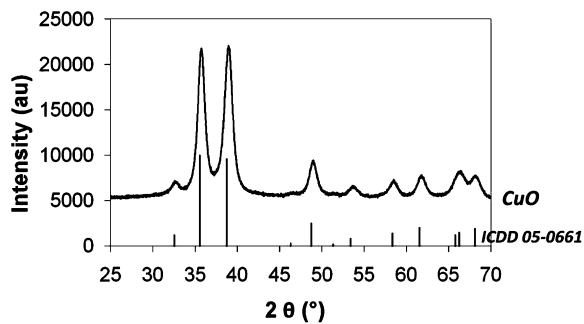

FIGURE 3. XRD of $\mathrm{CuO}\left(65 \mathrm{~m}^{2} / \mathrm{g}\right)$ from $\mathrm{Cu}$-oxalate assigned to the XRD of tenorite form (ICDD 05-0661).

three times. The experimental points in Figures 6-10 were an average of the experimental data. The recovery percentage by the experimental method used was $91.7 \pm 2.7 \%$.

\section{RESULTS AND DISCUSSSION}

Thermogravimetry of $\mathrm{Cu}$-oxalate. The TGA curve of the Cu-oxalate powder is shown in Figure 2 showing three steps. The weight loss between 30 and $200{ }^{\circ} \mathrm{C}$ can be attributed to adsorbed water followed by a step between 200 and $275{ }^{\circ} \mathrm{C}$ due to the decomposition of the polymer hydroxypropyl-methylcellulose (HPMC). The third step beginning at $275{ }^{\circ} \mathrm{C}$ shows the rapid weight loss due to the decomposition of the $\mathrm{Cu}$-oxalate into the $\mathrm{CuO}$. The oxalate route followed a very slow and controlled thermal decomposition in air. This was the best route to obtain microsize particles of $\mathrm{CuO}$ with a reproducible high specific surface area and controlled morphology (see SEM in Figure 5).

$X$-ray Diffraction, Surface Specific Area (SSA), and Mean Aggregate $\left(d_{v 50}\right)$ Size of $\mathrm{CuO}$ Powders. Figure 3 shows the X-ray diffraction on of $\mathrm{CuO}$ obtained from the Cu-oxalate as described in Reagents and Synthesis of high-surface-area $\mathrm{CuO}$ in the Experimental Section. Relation 2 , based on the XRD, determined the size of the primary crystallite at $13 \mathrm{~nm}$. This agrees with the value of $12 \mathrm{~nm}$ estimated from relation 3 above for the single particle size of $\mathrm{CuO}$ from the SSA measurements. The particle size distribution (PSD) is presented in Figure 4 and the median size of the aggregate was $1.85 \mu \mathrm{m}$ was observed implying a high porosity being present in the $\mathrm{CuO}$.

Scanning Electron Microscopy of $\mathrm{CuO}$ (SEM). From the SEM picture in Figure $5 \mathrm{a}$, we could observe the morphology of the CuO powder, composed of cubic particles around $2 \mu \mathrm{m}$ in size. The narrow particle size distribution measured by laser diffraction in Figure 4 confirms the narrow size distribution observed by SEM and the median size measured of $d_{\mathrm{v} 50}=1.85 \mu \mathrm{m}$, as observed in Figure $5 \mathrm{a}$.
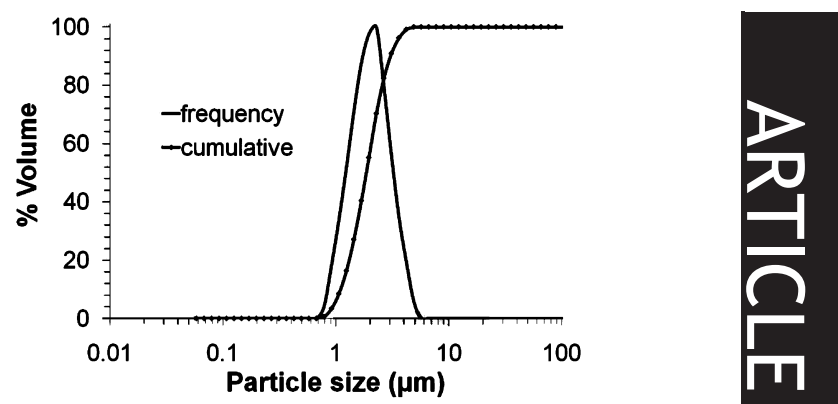

FIGURE 4. Particle size distribution measured by laser diffraction (Malvern Mastersizer) for $\mathrm{CuO}\left(65 \mathrm{~m}^{2} / \mathrm{g}\right)$.

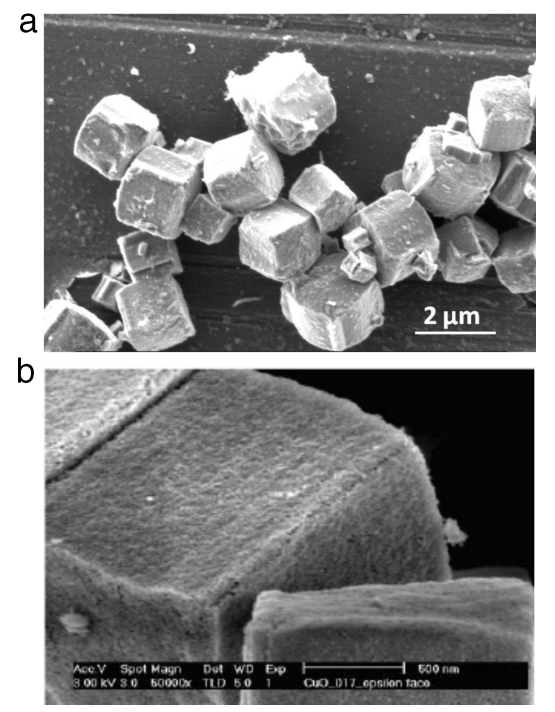

FIGURE 5. (a) SEM of CuO powders having $65 \mathrm{~m}^{2} / \mathrm{g}$. (b) SEM of $\mathrm{CuO}$ showing the detailed structure of the cubic crystallites

Figure $5 \mathrm{~b}$ presented the SEM of $\mathrm{CuO}$ powders having 65 $\mathrm{m}^{2} / \mathrm{g}$ shows the detailed structure of the cubic crystallites. If we take the known relation for the size of the $\mathrm{CuO}$ particle $d_{\mathrm{BET}}=6000 /\left(S_{\mathrm{BET}} \rho\right)$, where BET is the specific surface area of $\mathrm{CuO}\left(65 \mathrm{~m}^{2} / \mathrm{g}\right)$ and $\rho$ is the $\mathrm{CuO}$ density $\left(6.5 \mathrm{~g} / \mathrm{cm}^{3}\right)$. This allows us to estimate that the primary particle size $d_{\mathrm{BET}}$ is $\sim 14 \mathrm{~nm}$ in the nanometer range.

E. coli Inactivation by Cotton/CuO $\left(65 \mathrm{~m}^{2} / \mathrm{g}\right)$ under Visible Light Irradiation. The beneficial effect of the RF-plasma on the cotton surface introducing additional binding sites can be seen in Figure 6. Figure 6 presents the E. coli $\mathrm{K} 12$ bacterial inactivation of cotton/CuO $\left(65 \mathrm{~m}^{2} / \mathrm{g}\right)$ samples. Trace a shows a negligible decrease of E. coli on cotton in the dark on samples not activated by RFplasma because little CuO sticks to the cotton surface. Trace b shows an increased E. coli inactivation within $4 \mathrm{~h}$ due to the highly oxidative species generated by $\mathrm{CuO}$ under light. The mechanism is described in the next section below. The additional binding sites introduced by RF-plasma on the cotton binds more $\mathrm{CuO}$, increasing the bacterial inactivation in the dark and under light as shown in traces $\mathrm{c}$ and $\mathrm{d}$, respectively.

The mechanism of E. coli inactivation in the dark by RFplasma CuO-loaded cotton samples in Figure 6e can be understood by the findings reported by our previous work (27). After the $\mathrm{CuO}$ is contacted with the bacterial suspension 


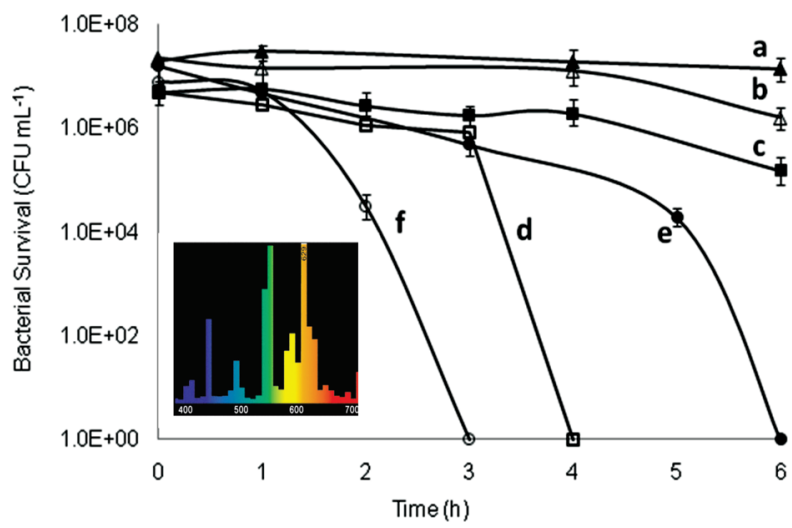

FIGURE 6. E. coli inactivation: (a) cotton alone, dark; (b) cotton under visible light irradiation from an Osram Lumilux T8-L18W source with 5 lamps $\left(4.7 \mathrm{~mW} / \mathrm{cm}^{2}\right)$; (c) cotton $/ \mathrm{CuO}\left(65 \mathrm{~m}^{2} / \mathrm{g}\right),(0.71 \% \mathrm{wt} / \mathrm{wt})$, dark; (d) cotton $/ \mathrm{CuO}\left(65 \mathrm{~m}^{2} / \mathrm{g}\right),(0.71 \mathrm{wt} \% / \mathrm{wt})$, under visible light irradiation from an Osram Lumilux T8-L18W source with 5 lamps $\left(4.7 \mathrm{~mW} / \mathrm{cm}^{2}\right)$; (e) RF-plasma cotton $/ \mathrm{CuO}\left(65 \mathrm{~m}^{2} / \mathrm{g}\right),(071 \mathrm{wt} \% / \mathrm{wt})$, dark; (f) RF-plasma cotton/CuO $\left(65 \mathrm{~m}^{2} / \mathrm{g}\right),(0.71 \mathrm{wt} \% / \mathrm{wt})$, under visible light irradiation from an Osram Lumilux T8-L18W source with 5 lamps $\left(4.7 \mathrm{~mW} / \mathrm{cm}^{2}\right)$. The inset shows the wavelength distribution of the Osram Lumilux T8-L18W lamp used in the bacterial inactivation.

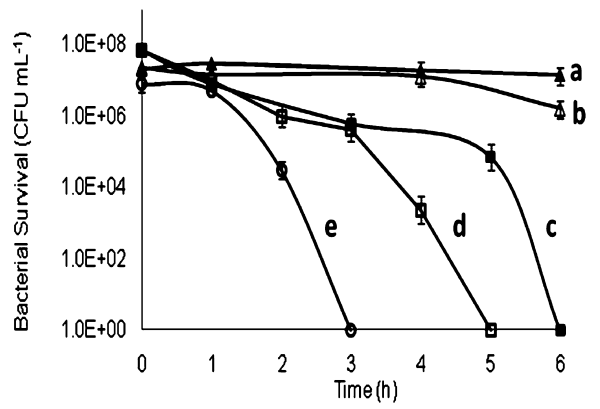

FIGURE 7. E. coli inactivation mediated by: (a) cotton alone, dark; (b) cotton under visible light irradiation from an Osram Lumilux T8L18W source with 5 lamps $\left(4.7 \mathrm{~mW} / \mathrm{cm}^{2}\right)$; (c) RF-plasma cotton $/ \mathrm{CuO}$, $\left(65 \mathrm{~m}^{2} / \mathrm{g}\right)$ with a loading of $0.71 \mathrm{wt} \% / \mathrm{wt}$ in the dark (ロ); (d) same as in c but under light irradiation of 1 lamp $(1.2 \mathrm{~mW} / \mathrm{cm} 2)$ (口); (e) same as in $\mathrm{d}$ under light irradiation of 5 lamps $\left(4.7 \mathrm{~mW} / \mathrm{cm}^{2}\right)(\bigcirc)$.

prepared in buffered solutions, some remarkable spectral changes were observed by XPS. The surface of $\mathrm{CuO}$ exposed to bacterial suspension almost completely changes its oxidation state from $\mathrm{Cu}^{2+}$ to $\mathrm{Cu}^{1+}$. Decomposition of the $\mathrm{Cu} 2 \mathrm{p}_{3 / 2}$ line reveals that the outermost layer of the catalyst becomes $80 \%$ in $\mathrm{Cu}_{2} \mathrm{O}$ and only $20 \%$ remains as $\mathrm{CuO}$. The evidence for this observation is the shift in the $\mathrm{Cu} 2 \mathrm{p}_{3 / 2}$ and $\mathrm{Cu} 2 \mathrm{p}_{1 / 2}$ lines positioned initially at 933.7 and $953.6 \mathrm{eV}$ to 932.6 and $952.6 \mathrm{eV}$, respectively for catalysts contacted with E. coli in the dark. Moreover, the concomitant disappearance of the $\mathrm{Cu}^{2+}$ shakeup satellite lines at 942.3 and $962.2 \mathrm{eV}$ indicated that transformation of $\mathrm{CuO}$ to $\mathrm{Cu}_{2} \mathrm{O}$ is taking place. Hence, the catalyst surface is almost immediately reduced after the $\mathrm{CuO}$ contacts the bacteria and remains in reduced state within the $4 \mathrm{~h}$ of dark reaction as shown in Figure 6, trace e.

Figure 7 shows the E. coli inactivation as a function of the applied light intensity. The bacterial inactivation time decreases as the intensity of the applied visible light was increased from $1.2 \mathrm{~mW} / \mathrm{cm}^{2}$ (1 lamp) to $4.7 \mathrm{~mW} / \mathrm{cm}^{2}$ (5 lamps).

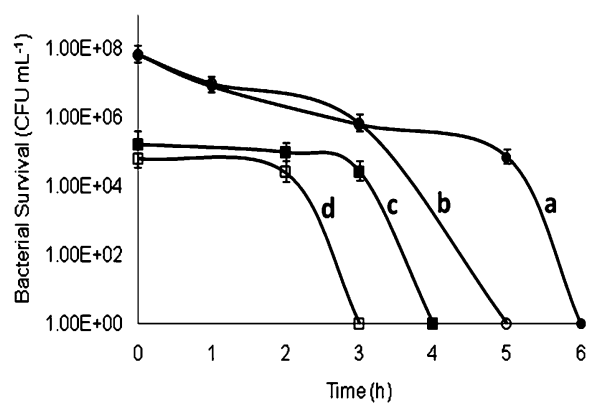

FIGURE 8. E. coli inactivation under visible light $\left(4.7 \mathrm{~mW} / \mathrm{cm}^{2}\right), \mathrm{RF}-$ plasma cotton $/ \mathrm{CuO}\left(65 \mathrm{~m}^{2} / \mathrm{g}\right)$ as a function of amount of $\mathrm{Cu}$ deposited on the cotton: (a) $\mathrm{CuO}(0.71 \mathrm{wt} \% / \mathrm{wt})$, dark (•); (b) $\mathrm{CuO}(0.71 \mathrm{wt}$ $\% / w t)$, light (O); (c) CuO (0.78 wt \%/wt), dark (口); (d) CuO (0.78 wt $\% / w t)$, light $(\square)$.

Reaction Mechanism of $\mathrm{CuO}$ under Illumination. The semiconductor character of $\mathrm{CuO}$ has been recently described (27). The main features are presented below. Under irradiation, $\mathrm{CuO}$ leads to oxidative radicals by a mechanism

$$
\mathrm{CuO}+h v(<720 \mathrm{~nm}) \rightarrow \mathrm{CuO}\left(\mathrm{e}_{\mathrm{cb}}^{-}, \mathrm{h}_{\mathrm{vb}}^{+}\right)
$$

The $\mathrm{e}_{\mathrm{cb}}^{-}$in eq 4 is produced from the $\mathrm{CuO}$ (p-type) with a band gap energy of $1.72 \mathrm{eV}$, a flat-band potential of $-0.3 \mathrm{~V}$ SCE (pH 7) and a valence band at $+1.4 \mathrm{~V} \mathrm{SCE} \mathrm{(26).} \mathrm{The}$ electron-hole pair is formed with photon energies exceeding the band gap of $\mathrm{CuO}$. The excited electron could either react (a) directly with the $\mathrm{O}_{2}$ forming $\mathrm{O}_{2}{ }^{--}$(reaction 5) or by (b) reducing the $\mathrm{Cu}^{2+}$ lattice to $\mathrm{Cu}^{+}$, leading to ensuing reactions 6 and 7 with formation of $\mathrm{O}_{2}{ }^{--}$radicals

$$
\begin{gathered}
\mathrm{CuO}\left(\mathrm{e}_{\mathrm{cb}}^{-}\right)+\mathrm{O}_{2} \rightarrow \mathrm{CuO}+\mathrm{O}_{2}^{--} \\
\mathrm{CuO}\left(\mathrm{e}_{\mathrm{cb}}^{-}\right) \rightarrow \mathrm{CuO}\left(\mathrm{Cu}^{+}\right) \\
\mathrm{CuO}\left(\mathrm{Cu}^{+}\right)+\mathrm{O}_{2} \rightarrow \mathrm{CuO}\left(\mathrm{Cu}^{2+}\right)+\mathrm{O}_{2}^{\cdot-}
\end{gathered}
$$

Equation 8 shows the equilibrium between $\mathrm{H}^{+}$and $\mathrm{O}_{2}{ }^{-{ }^{-}}$leads to the formation of the $\mathrm{HO}_{2}{ }^{\bullet}$ radical. The $\mathrm{HO}_{2}{ }^{\bullet}$ stated in eq 8 leads to the production of adsorbed $\mathrm{H}_{2} \mathrm{O}_{2}$ in $\mathrm{CuO}$ eq 9

$$
\mathrm{H}^{+}+\mathrm{O}_{2}^{-} \Leftrightarrow \mathrm{HO}_{2}^{-}\left(\text {partial } \mathrm{O}_{2}^{--}\right) \mathrm{p} K_{\mathrm{a}}=4.8
$$

$$
\mathrm{CuO}\left(\mathrm{Cu}^{+}\right)+\mathrm{HO}_{2}^{\cdot}\left(\text { partial } \mathrm{O}_{2}^{--}\right)+\mathrm{H}^{+} \rightarrow \mathrm{CuO}\left(\mathrm{Cu}^{2+}\right)+\mathrm{H}_{2} \mathrm{O}_{2}
$$

with $k_{8}=0.6-2.3 \mathrm{M}^{-1} \mathrm{~s}^{-1}$ (34).

Inactivation of $E$. coli As a Function of the $\mathrm{CuO}$ Content on the Cotton Textile. Figure 8 presents the inactivation of $E$. coli as a function of the amount of $\mathrm{CuO} /$ $\mathrm{cm}^{2}$ on the cotton surface. Trace $8 \mathrm{a}$ shows the bacterial inactivation with a sample cotton/CuO $(0.71 \% \mathrm{Cu} w t / w t)$ in 


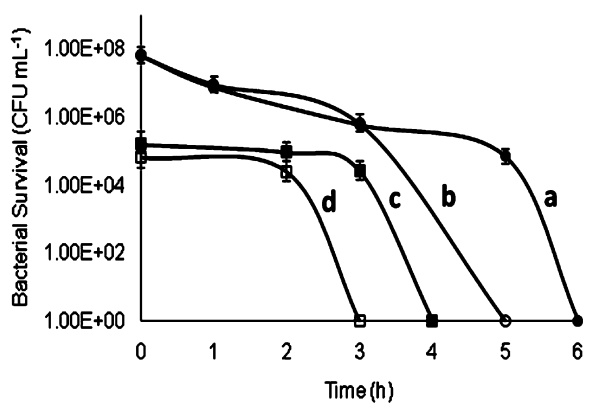

FIGURE 9. Bacterial inactivation, RF-plasma cotton $/ \mathrm{CuO}\left(65 \mathrm{~m}^{2} / \mathrm{g}\right)$ (0.71 wt \%/wt), under visible illumination as a function of initial number of E. coli, 1 lamp $\left(1.2 \mathrm{~mW} / \mathrm{cm}^{2}\right)$ : (a) dark (•), (b) light (O), (c)

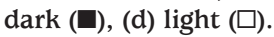

the dark and trace $8 \mathrm{~b}$ shows the faster inactivation of $E$. coli by the same cotton/CuO sample under visible light. The beneficial effect on the E. coli inactivation by $\mathrm{CuO}$ under band gap irradiation because of its semiconductor behavior has been described in the previous section. Trace $8 \mathrm{~d}$ for a cotton sample having a higher $\mathrm{CuO}$ loading of $0.78 \% \mathrm{Cu} w \mathrm{t} /$ wt inactivated under visible light irradiation the E. coli within $3 \mathrm{~h}$. The E. coli inactivation kinetics is the same as found for the sample with a lower loading of $(0.71 \% \mathrm{Cu} w t / w t)$ in shown in trace $8 \mathrm{~b}$. This means that above a certain loading of $\mathrm{Cu}$, the $E$. coli inactivation kinetics does not strongly depend on the amount of $\mathrm{CuO}$ on the cotton within $\mathrm{CuO}$ range screened in this study. This result is meaningful in the following context: In the way we prepare the CuO suspensions from the $\mathrm{CuO}\left(65 \mathrm{~m}^{2} / \mathrm{g}\right)$, we tried several ways to vary in a wider range the $\mathrm{CuO}$ loading of the cotton aiming at relative short times for $E$. coli inactivation. But only the loading range of $0.70-0.80 \% \mathrm{Cu} w t / w t$ an acceptable $E$. coli inactivation kinetics was observed, and higher loadings did not lead to an improved $E$. coli inactivation kinetics.

Bacterial Inactivation Kinetics As a Function of the Initial Amount of E. coli. Figure 9 shows the $E$. coli inactivation kinetics for two different initial bacterial concentrations on cotton/CuO $\left(65 \mathrm{~m}^{2} / \mathrm{g}\right)$ in the dark and under light. The lowest visible light intensity of $1.2 \mathrm{~mW} / \mathrm{cm}^{2}$ (1 lamp) was applied. This light intensity used was is about $1 \%$ of the full sunlight intensity (AM 1) and this low light intensity was seen to have a significant effect enhancing bacterial inactivation. As noted in the captions in Figure 9, the E. coli inactivation kinetics increases when visible light is applied and also becomes faster as expected when the initial concentration of $E$. coli decreases.

Inactivation of $E$. coli under Suntest Light Irradiation: Test of Commercial CuO. Figure 10 presents the results of the bacterial inactivation for $E$. coli starting with a higher bacterial concentration of $1 \times 10^{10}$ $\mathrm{CFU} / \mathrm{mL}$ in the dark and under light. Traces $\mathrm{a}$ and $\mathrm{b}$ present the bacterial inactivation by cotton in the dark and under light. The increased activity of the cotton under sunlight with a dose of $27 \mathrm{~mW} / \mathrm{cm}^{2}$ is probably due to the tensides, bacterial amylase, networking agents, stabilizer, and organic peroxides added in the finishing steps in cotton fabrics ready for use. These additives generate under light intermediates and radicals leading with bactericide action (33). The light

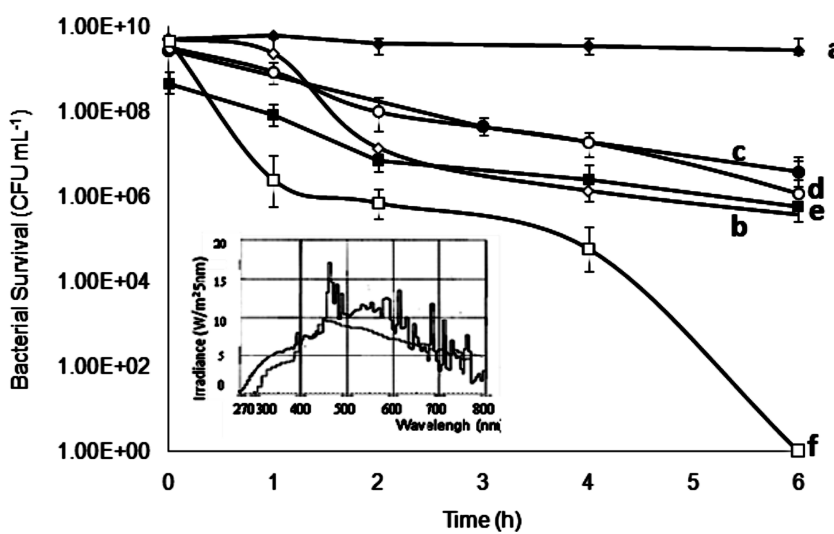

FIGURE 10. E. coli inactivation under Suntest simulated radiation (27 mW/ $\mathrm{cm}^{2}$ ): (a) cotton, dark ( $\diamond$ ); (b) cotton, light ( $\left.\diamond\right)$; (c) RF-plasma cotton/CuO commercial $\left(1 \mathrm{~m}^{2} / \mathrm{g}\right)$, dark (•); (d) RF-plasma cotton/CuO commercial(1 m2/g), light (O); (e) Rfplasma cotton $/ \mathrm{CuO}(65 \mathrm{~m} 2 / \mathrm{g})$, dark ( $\square$ ); (f) RF-plasma cotton $/ \mathrm{CuO}\left(65 \mathrm{~m}^{2} / \mathrm{g}\right)$, light ( $\left.\square\right)$. The insert shows the wavelength profile of the Suntest lamp.

intensity used in Figure 10 is about 6 times bigger than the light intensity used in Figure 6 and this is probably the cause for the E. coli partial inactivation under light shown in trace b compared to the almost negligible effect of light on cotton shown in Figure 6. Trace c confirms that the RF-plasma pretreated cotton loaded with commercial low-surface-area $\mathrm{CuO}\left(1 \mathrm{~m}^{2} / \mathrm{g}\right)$ was more active than pure cotton in the dark and the activity also increased under light as expected. The last two traces, e and f, show the significant higher bacterial inactivation of $E$. coli by pretreated cotton loaded with high surface area $\mathrm{CuO}\left(65 \mathrm{~m}^{2} / \mathrm{g}\right)$ in the dark and even more under light because of the light irradiation on the $\mathrm{CuO}$ band gap.

The CuO having $65 \mathrm{~m}^{2} / \mathrm{g}$ has a particle radius of $13 \mathrm{~nm}$ as determined by the SSA measurements. If we take spherical geometry for these particles, the sphere has a surface of $2 \times 10^{3} \mathrm{~nm}^{2}$ and for the $65 \mathrm{~m}^{2} / \mathrm{g}$ there would be $3.3 \times 10^{16}$ sites/g $\mathrm{CuO}$.

A rough estimation can be made for the amount of $\mathrm{CFU}$ inactivated by one photon. In our experiments we used 20 $\mu \mathrm{L}$ of a sample of $E$. coli $10^{3} \mathrm{CFU} / \mathrm{mL}$ on $4 \mathrm{~cm}^{2}$ cotton/CuO and applied for $6 \mathrm{~h}$ Suntest light emitting $2 \times 10^{17}$ photons/ $\mathrm{cm}^{2} / \mathrm{s}$ to inactivate completely the bacteria. We estimate that around $7 \mathrm{CFU}$ were inactivated per incident photon. The high number of CFU inactivated per incident photon may be due to three factors: (a) the secondary reactions on the cotton leading to E. coli deactivation, (b) chain reactions occurring during the bacterial inactivation process, and (c) the hotelectrons produced during the cotton RF-pretreatment.

\section{CONCLUSIONS}

- The first report is presented for cotton/CuO modified bactericide textiles using large surface area $\mathrm{CuO}$ with enhanced adhesion of the $\mathrm{CuO}$ due to the RF-plasma treatment. The RF-plasma pretreatment introduces additional binding sites on the cotton with beneficial effects on the $E$. coli inactivation.

- This work reports on the preparation method and characterization of large surface area $\mathrm{CuO}$ nanoparticles.

- The present findings indicate that low intensity visible light with about $1 \%$ of the full solar irradiation had a 
significant effect on the inactivation of $E$. coli mediated by $\mathrm{CuO}$ powders.

Acknowledgment. V.S. thanks the support of the Bank of the Colombian Republic through the Foundation for the Promotion and Advancement of Science and Technology. We thank the COST Action MP0804 Highly Ionised Pulse Plasma Processes (HIPP) for support of this work.

\section{REFERENCES AND NOTES}

(1) Yuranova, T.; Rincon, G. A.; Laub, D.; Kiwi, J. Catal. Today 2007 122, $109-117$.

(2) Kiwi, J.; Pulgarin, C. Catal Today. 2010, 151, 2-7.

(3) Ilic, V.; Saponjic, Z.; Vodnik, V.; Mihailovic, D.; Jovancic, P.; Nedeljkovic, J.; Radetic, M. Fiber Polym. 2009, 10, 650-657.

(4) Melaiye, A.; Sun, Z.; Hindi, K.; Milstedt, A.; Ely, D.; Reneker, D.; Tessier, C.; Youngs, W.J. Am. Chem. Soc. 2005, 127, 2285-2291.

(5) Mills, A; LeHunte, S. J. Photochem. Photobiol., A 1997, 108, 1-35.

(6) Yuranova, T.; Rincon, G. A.; Bozzi, A.; Parra, S.; Pulgarin, C.; Albers, P.; Kiwi, J. J Photochem. Photobiol., A 2003, 161, 27-34

(7) Bozzi, A.; Yuranova, T.; Kiwi, J.J. Photochem. Photobiol., A 2005, 172, 27-34

(8) Radetic, M.; Ilic, V.; Vodnik, V.; Dimitrijevic, S.; Jovancic, P.; Saponjic, S.; Nedelkovic, J. Polym. Adv. Technol. 2008, 19, $1816-$ 1821.

(9) Ilic, V.; Saponjic, Z.; Vodnic, V.; Molina, R.; Dimitrijevic, S.; Jovancic, P.; Nedelkovic, J.; Radetic, M. J. Mater. Sci. 2009, 44, 3983-3989.

(10) Ki, K.; Chen, X.; Liu, L.; Xin, J.; Mak, C.; Daoud, A. W. J. Mater. Chem. 2007, 17, 3504-3510.

(11) Daoud, W. A.; Xin, J. H.; Zhang, Y. H. Surf. Sci. 2005, 599, 6975

(12) Tung, W. S.; Daoud, W. A. J. Colloid Interface Sci. 2008, 326, $283-$ 290.

(13) Gao, Y.; Cranston, R. Text. Res. J. 2005, 78, 60-66

(14) Czajka, R. Fiber Text. East Eur. 2005, 13, 13-16.

(15) Alt, V.; Bechert, T.; Steinrucke, P.; Wegener, M.; Schnettler, R.
Biomaterials 2004, 25, 4383-4391.

(16) Lee, H.; Jeong, H. Textile Res., J. 2005, 75, 551

(17) Yuranova, T.; Rincon, G. A.; Pulgarin, C.; Laub, D.; Xanthopoulos, N.; Mathieu, H.-J.; Kiwi, J.J. Photochem. Photobiol., A 2006, 181, 363-369

(18) Kasanen, J.; Suvanto, M.; Pakkanen, T.J. Appl. Polym. Sci. 2009, 111, 2597-2603

(19) Karlin, D. K.; Gulneth, Y. In Progress in Inorganic Chemistry; Lippard, S. J., Ed.; Wiley: New York, 1987; Vol. 35, pp 220-237.

(20) Hostynek, J.; Maibach, I. Rev. Environ. Health 2003, 18, 153-183.

(21) Borkow, G.; Gabbay, J. FASE 2004, 18, 1728-1730.

(22) Borkow, G.; Gabbay, J. J Med. Hypothesis 2008, 70, $990-994$

(23) Malnick, S.; Bardenstein, R.; Huszar, M.; Gabbay, J.; Borkow, G. J. Hosp. Infect. 2008, 70, 89-92.

(24) Bandara, J.; Kiwi, J.; Pulgarin, C.; Peringer, P.; Pajonnk, G.-M.; Elaloui, A.; Albers, P. Env. Sci. Technol 1996, 20, 1261-1267.

(25) Moshe, T.; Dror, T.; Berkowitz, T. Appl. Catal., B 2009, 85, 207 212

(26) Bandara, J.; Bowen, P.; Soare, L.; Jardim, W.; Kiwi, J. Langmuir 2005, 21, 8554-8559.

(27) Paschoalino, M.; Guedes, N.; Jardim, W.; Mielczarski, E.; Mielczarsi, J.; Bowen, P.; Kiwi J. Photochem. Photobiol., A 2008, 199, 105-111

(28) Gabbay, J.; Mishal, J.; Magen, E.; Zatcoff, R. C.; Shemer-Avni, Y.; Borkow, G. J. Ind. Text. 2006, 35, 323-35.

(29) Jongen, N.; Hoffmann, H.; Bowen, P.; Lemaitre, L. J. Mater. Sci. Lett. 2000, 19, 1073-1075.

(30) Balzar, D.; Audebrand, N.; Daymond, M.; Fitch, M.; Hewat, A.; Langford, J.; Le Bail, A.; Louer, B.; Mason, O., Toby, B. http:// journals.iucr.org/j/issues/2004/086/00/ks0213/ks0213hdr.html.

(31) Bowen, P.J. Dispersion Sci. Technol. 2002, 23, 631-640.

(32) ISO Standard 20743, Sept 2007, Evaluation of the antibacterial activity of biocidal products (www.afnor.org).

(33) Cilander A. G., private communication.

(34) Goldstein, S.; Czapski, G.; Meyerstein, D.J. Am. Chem. Soc. 1990, $112,6489-6493$.

AM100370Y 